\title{
NEW APPROACH FOR n-HEXADECANE BIODEGRADATION BY SOL-GEL ENTRAPPED BACTERIAL CELLS
}

\author{
NOWE PODEJŚCIE DO BIODEGRADACJI n-HEKSADEKANU \\ PRZEZ KOMÓRKI BAKTERYJNE UWIĘZIONE \\ W MATERIALE ZOL-ŻELOWYM
}

\begin{abstract}
In this study sol-gel hybrid materials in the system $\mathrm{SiO}_{2}$-chitosan (CS) - polyethylene glycol (PEG), as novel structures with potential application in bioremediation were investigated. The organic components - CS and PEG were used as structural modifiers for functionality improvement. The catabolic activity to n-hexadecane of Pseudomonas aeruginosa BN10 free and immobilized cells was estimated. The cell immobilization technique was employed to evaluate its efficiency on biodegradation and protective effect from high levels of hydrocarbons. The characteristics of obtained hybrid materials were investigated via X-ray Diffraction (XRD), Fourier transform infrared spectroscopy (FTIR), Scanning Electron Microscopy (SEM) and Atomic-force microscopy (AFM) analyses. The obtained results revealed that the organic part in the synthesized hybrids is important for microstructure and defined properties creation. The rate of $n$-hexadecane mineralization by the bacterial strain was influenced by variation in cell densities applied in the immobilization procedures. Semi-continuous processes with multiple xenobiotic supplies were carried out. The synthesized by the sol-gel method hybrid matrices proved to be suitable carriers for realizing an effective biodegradation process of n-hexadecane by Pseudomonas aeruginosa BN10. Biodegradation of $50 \mathrm{~kg} / \mathrm{m}^{3}$ of $\mathrm{n}$-hexadecane was realized by free cells. Significantly greater quantity $\left(150 \mathrm{~kg} / \mathrm{m}^{3}\right)$ was mineralized for 15 active cycles by entrapped bacterial cells. Biodegradation process with gradual increase of xenobiotic concentration reaching $30 \mathrm{~kg} / \mathrm{m}^{3}$ for $120 \mathrm{~h}$ was also accomplished.
\end{abstract}

Keywords: biodegradation, n-hexadecane, hybrids, sol-gel, Pseudomonas aeruginosa

\section{Introduction}

Pollution, due to petroleum oil, is a prevalent ecological hazard and hence, microbial degradation of hydrocarbons remains a top issue [1]. The occurrence of oil contamination in the environment is very common. Petroleum oil contains high levels of persistent hydrocarbons which can negatively affect ecosystems. n-hexadecane comprises the largest part of the aliphatic fraction of petroleum oil. The ability of microorganisms to degrade pollutants due to their diverse metabolic capabilities is an evolving approach for the

\footnotetext{
${ }^{1}$ Department of Silicate Technology, University of Chemical Technology and Metallurgy, 8 Kliment Ohridski blvd., Sofia 1756, Bulgaria

${ }^{2}$ Institute of Microbiology "Stephan Angeloff”, Bulgarian Academy of Sciences, "Acad. G. Bonchev" str., bl. 26, Sofia 1113, Bulgaria

*Coresponding author: lkabaivanova@yahoo.com
} 
removal of many environmental pollutants including the products of petroleum industry $[2,3]$. Biodegradation by microorganisms represents one of the primary mechanisms by which petroleum and other hydrocarbon pollutants that can be found in rivers, as a result of routine petroleum activities or by accidental oil spills can be removed from the environment [4]. Both aliphatic and aromatic fractions are very often found in nature under oil forms and represent a real danger of pollution for the environment due to the difficulty of their biodegradation [5-7].

The sol-gel route becomes one of the traditional methods for synthesis of different types of hybrid materials - functional drug delivery carriers, mesoporous adsorbents, coatings and thin films for corrosion protection, biosensors, nanomaterials etc. [8, 9]. In the last few years it was established that hybrid materials, based on silica are suitable for immobilization of different biological objects [10]. The silica material could be easily prepared via sol-gel method, as its functionality and biocompatibility depends on the organic part involved [11]. Chitosan in combination with polyethylene glycol is an organic mixture, which is applied in different biotechnological schemes due to their biocompatibility, biodegradability and reactivity (PEG, containing hydroxyl groups and chitosan - hydroxyl and amino end groups for which is established that they posses different affinity to biological objects). Influence on bioactivity plays the length of the organic chain - the long chains exhibit reduced value of free reactive groups [12]. The combination of these organic components with the silica network allows formation of hybrid structures, exhibiting improved properties. They possess properties of both organic and inorganic constituents such as good permeability, selectivity, mechanical strength, and thermal and chemical stability, as well as good biological compatibility [13]. A wide range of polymers have been tested in the attempt to develop supports for successful cell immobilization with different purposes $[14,15]$. Immobilized cells have been used and studied for the bioremediation of numerous toxic chemicals. Immobilization not only simplifies separation and recovery of immobilized cells but also makes the preparations reusable which reduces the overall cost [16]. Immobilization results in an increased contact between cells and hydrocarbon droplets. Diaz et al. [17] report that immobilization of bacterial cells enhances the biodegradation rate of crude oil compared to free living cells in a wide range of culture salinity.

The aim of the study was to synthesize novel hybrid materials by the sol-gel method in the system $\mathrm{SiO}_{2}$-chitosan (CS) - polyethylene glycol (PEG) and to use them as matrices for immobilization of Pseudomonas aeruginosa BN10 for realization of an effective xenobiotic biodegradation process.

\section{Materials and methods}

\section{Microorganism, media, cultivation}

Pseudomonas aeruginosa strain BN10 was maintained on nutrient agar slants (Difco Laboratories, Detroit, MI, USA) at $4{ }^{\circ} \mathrm{C}$. Starting cultures were prepared by transferring bacterial cells from the storage culture to $250 \mathrm{dm}^{3}$ flasks containing $50 \mathrm{dm}^{3}$ of nutrient broth and incubation at $30{ }^{\circ} \mathrm{C}$ and $150 \mathrm{rpm}$ on a rotary shaker for 7 days. Mineral salt medium with the following composition: $\mathrm{K}_{2} \mathrm{HPO}_{4} \cdot 3 \mathrm{H}_{2} \mathrm{O}\left(7.0 \mathrm{~kg} / \mathrm{m}^{3}\right) ; \mathrm{KH}_{2} \mathrm{PO}_{4}\left(3.0 \mathrm{~kg} / \mathrm{m}^{3}\right)$; $\left(\mathrm{NH}_{4}\right)_{2} \mathrm{SO}_{4}\left(1.0 \mathrm{~kg} / \mathrm{m}^{3}\right) ; \mathrm{MgSO}_{4} \cdot 7 \mathrm{H}_{2} \mathrm{O}\left(0.2 \mathrm{~kg} / \mathrm{m}^{3}\right)$ were used. The $\mathrm{pH}$ value of the medium was adjusted to 7.0. The carbon source was n-hexadecane (1\% v/v) which was sterilized through $0.2 \mu \mathrm{m}$ membrane filters (Milipore Corp., Bedford, Mass) before its addition to the 
medium. Microorganism growth was monitored by measuring the optical density at $610 \mathrm{~nm}$ $\left(O D_{610}\right)$.

\section{Hybrid synthesis and structural investigations}

For preparation of silica hybrid materials with participation of chitosan and polyethylene glycol the following components were used: tetraethylorthosilicate (TEOS, $98 \%$ ), chitosan (CS, DD, $75 \%$ ), acetic acid (99.8\%), polyethylene glycol (PEG, MW 400), calcium chloride $\left(\mathrm{CaCl}_{2}, 98 \%\right.$ ), buffer solution (FICSAL, pH 7.0, containing $\left.\mathrm{Na}_{2} \mathrm{HPO}_{4} \cdot 2 \mathrm{H}_{2} \mathrm{O}-\mathrm{KH}_{2} \mathrm{PO}_{4}\right)$, hydrochloric acid $(\mathrm{HCl}, 37 \%)$, distilled water $\left(\mathrm{dH}_{2} \mathrm{O}\right)$.

The ratios of initial components used for preparation of the desired hybrids were:

- $\quad$ TEOS/CS/PEG $=1 / 0.056 / 0.056($ SiCSPCa1)

- $\quad$ TEOS/CS/PEG = 1/0.333/0.333 $($ SiCSPCa2)

\section{Cells immobilization}

A poly-step sol-gel procedure was performed at strictly controlled conditions in order to obtain the desired materials.

Bacterial cells were harvested by centrifugation at $8000 \times \mathrm{g}$ and re-suspended in phosphate buffer $\left(0.06 \mathrm{M}, \mathrm{pH} 7.0\right.$ at $\left.20{ }^{\circ} \mathrm{C}\right)$ to obtain a cell density of $3.0 \cdot 10^{10} \mathrm{~g}^{-1}$ carrier material and were added to the precursors solution. Five $\mathrm{dm}^{3}$ of cell suspension were introduced in the flasks for implementation of the process of $n$-hexadecane biodegradation.

The mixture was introduced into a mould made of two flat glass plates and the polymerization was allowed to proceed at ambient temperature for $20 \mathrm{~min}$. The $3 \mathrm{~mm}$ thick gel, containing entrapped cells was cut into blocks of approximately $3 \times 3 \times 3 \mathrm{~mm}$. The gel particles were washed with distilled water and further used for conveying semi-continuous cultivation in $250 \mathrm{dm}^{3}$ flasks. Xenobiotic was supplied at the beginning of each reaction cycle.

\section{n-hexadecane biodegradation}

Biodegradation of hexadecane was measured as substrate depletion. Whole cultures $\left(50 \mathrm{dm}^{3}\right)$ were extracted with the same volume of $\mathrm{n}$-hexane $\left(50 \mathrm{dm}^{3}\right)$ and residual xenobiotic (n-hexadecane) was quantified by gas chromatography using a Hewlett-Packard model 5859 instrument equipped with a flame ionization detector.

\section{Results and discussion}

\section{Sol-gel hybrid matrices characterization}

Hybrid sol-gel matrices were synthesized and their structure was examined. The phase composition of obtained hybrid materials was investigated via X-ray diffraction analysis (Fig. 1). The patterns presented halo around 23 2-Theta, which is due to formation of amorphous Si-O-Si network. The absence of other intensive peaks and sharpness of the halo are associated with even distribution of the used organic components.

In the obtained FTIR spectra (Fig. 2) the characteristic peaks of the main units in the hybrid structures of silica network (asymmetric and symmetric stretching vibrations - at $1080 \mathrm{~cm}^{-1}$ and $450,560,790 \mathrm{~cm}^{-1}$, respectively) were established. Due to the applied synthesis technique at ambient conditions, on the FTIR spectra also exist peaks of Si-OH $\left(950 \mathrm{~cm}^{-1}\right)$ and $\mathrm{H}-\mathrm{OH}$ groups $\left(\sim 1640\right.$ and $\left.3400 \mathrm{~cm}^{-1}\right)$. 


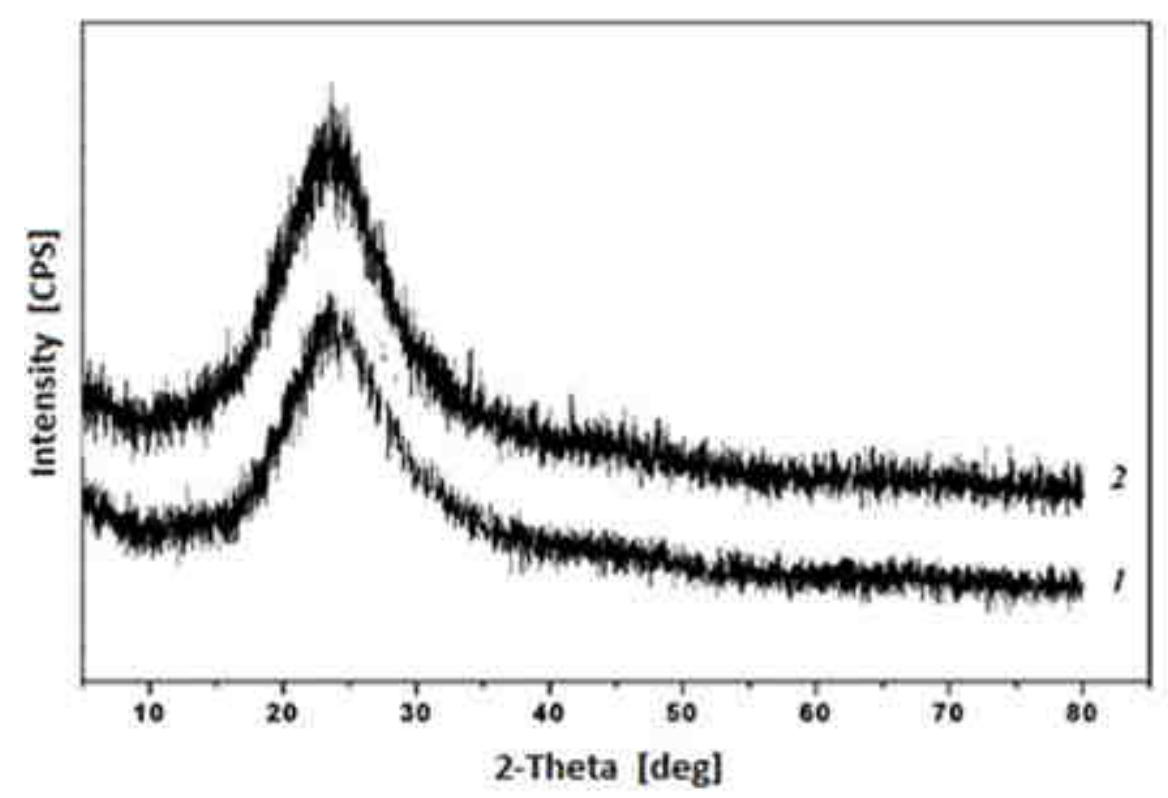

Fig. 1. XRD patterns of obtained silica hybrid materials: 1) SiCSPCa1 and 2) SiCSPCa2

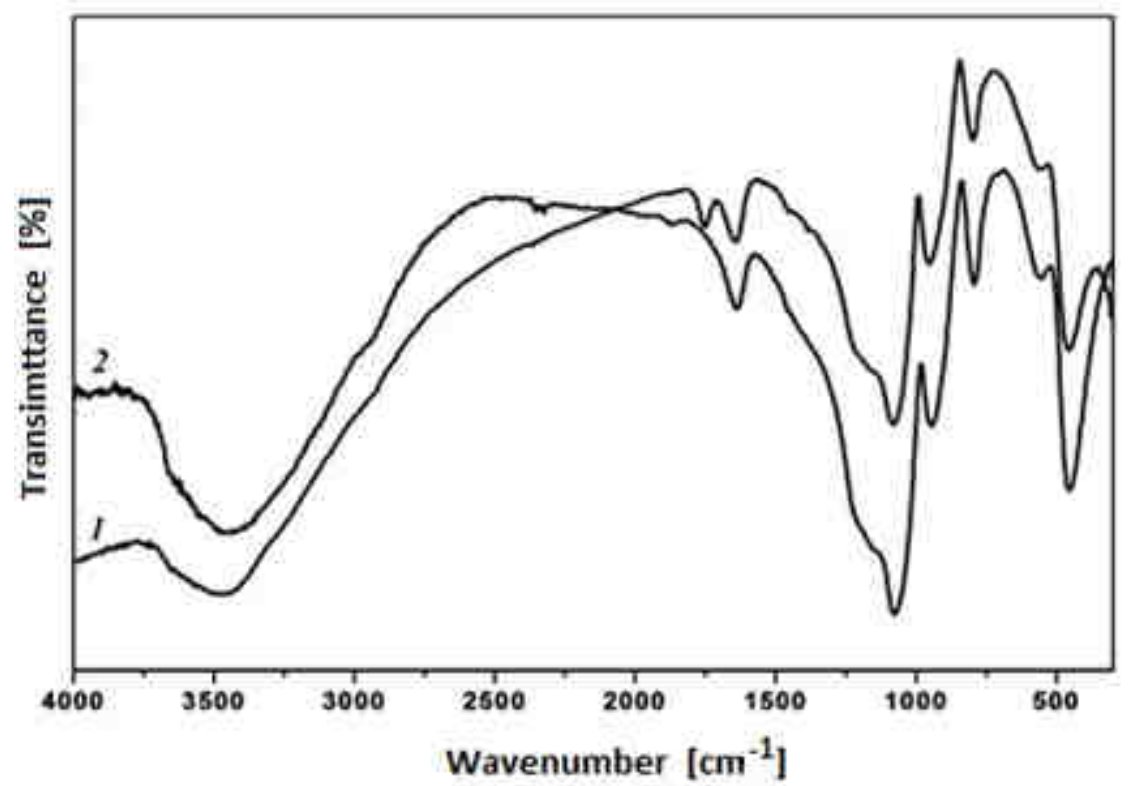

Fig. 2. FTIR spectra of synthesized hybrid materials: 1 - SiCSPCa1 and 2 - SiCSPCa2

The peak with reduced intensity at $1450 \mathrm{~cm}^{-1}$ is associated with amino groups of chitosan. The typical peaks of this organic component corresponding to $\mathrm{C}-\mathrm{OH}$ and $\mathrm{C}-\mathrm{C}$ 
units are in the range of $1000-1200 \mathrm{~cm}^{-1}$. Significant difference between the two spectra is associated with the peak at $1760 \mathrm{~cm}^{-1}$ (SiCSPCa1), which corresponds to the added PEG. The absence of this peak with increasing the organic value can be associated with potential interaction between PEG and the other organic component. Furthermore, increased intensity of the peak at $1640 \mathrm{~cm}^{-1}$, which can confirm potential interaction between the amino groups of CS and end groups of PEG is visible. The microstructure of synthesized hybrids was visualized by SEM (Fig. 3). The micrographs presented differences in the structure with variation of the organic values.

a)

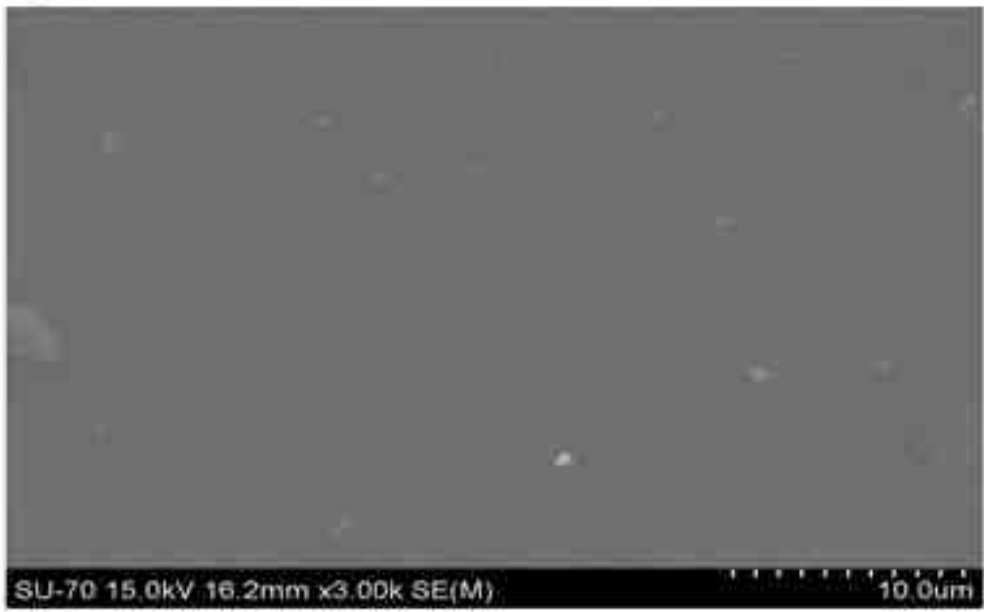

b)

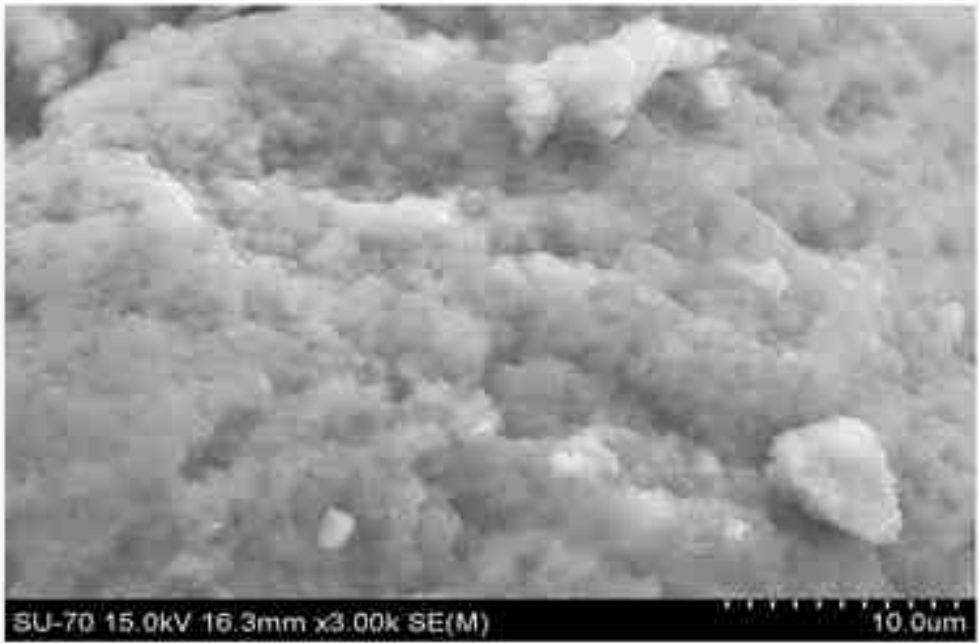

Fig. 3. SEM micrographs of synthesized hybrid materials: a) SiCSPCa1, b) SiCSPCa2 
The surface of hybrid SiCSPCa1 presented formation of smooth, homogeneous structure, based on silica network into which organic particles are evenly distributed. Increasing the organic values led to formation of unhomogeneous structure with huge amount of particles and aggregates on the hybrid surface. The roughness can be associated with potential interaction between the used organic components, which is established from the FTIR spectra. As a result of the interactions long organic chains are formed. Furthermore, scientific reports showed, that with increasing the $\mathrm{pH}$ of hybrid sols (by addition of buffer solution), the chitosan units are shrunk [18]. Due to this property of CS the shrinkage of the organic chains led to formation of aggregates, which are visible on the micrograph.

a)
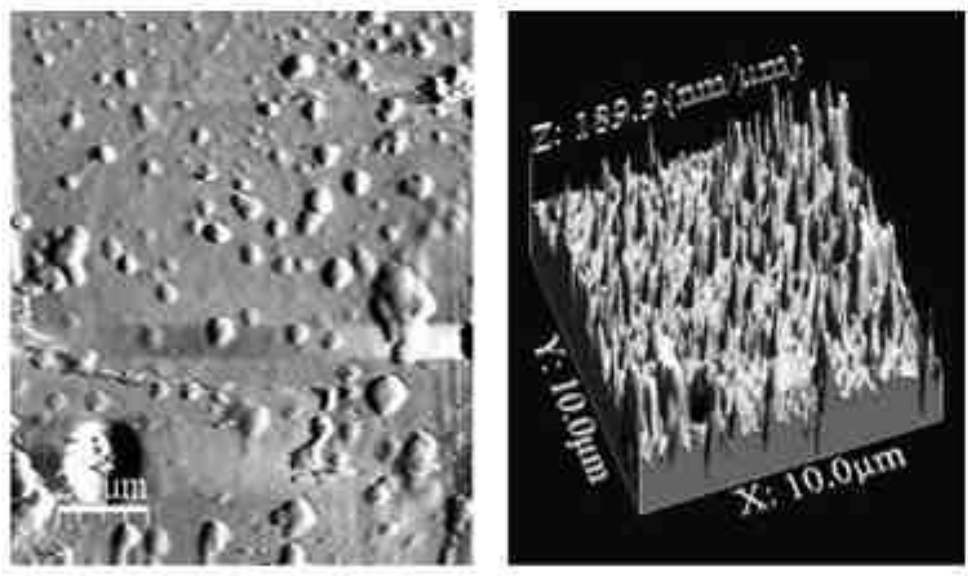

b)
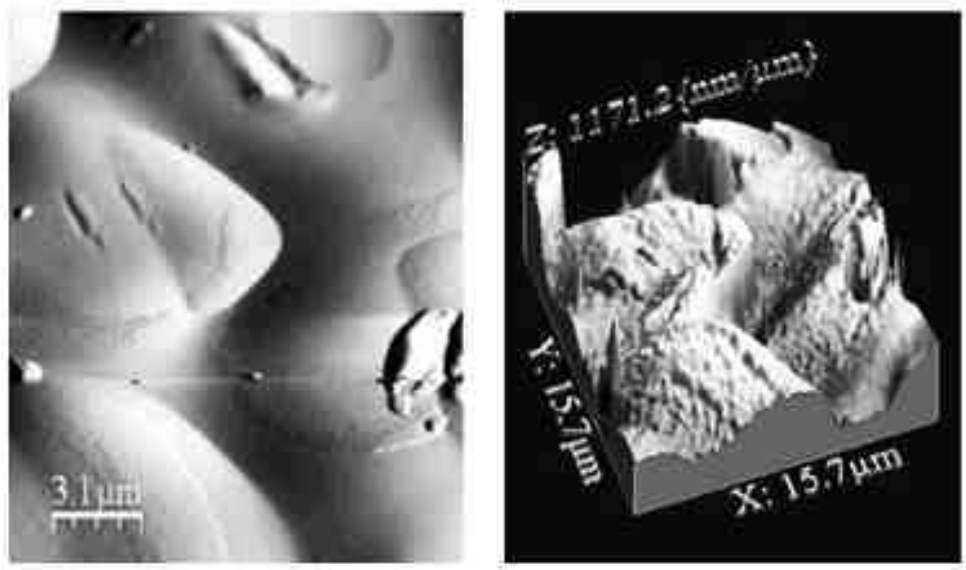

Fig. 4. AFM images of synthesized hybrid materials: a) SiCSPCa1, b) SiCSPCa2 
The surface characteristics of obtained hybrid materials were followed by AFM. The 2D and 3D micrographs, which are presented on Figure 4 reveal formation of homogeneous structure, with evenly distributed organic particles (SiCSPCa1) and rough surface (SiCSPCa2). The obtained results are in accordance with SEM investigations.

The results presented on Figure 5 showed, that the particle size (topo on $\mathrm{x}$ axis) for sample SiCSPCa1 varied between 10 and $150 \mathrm{~nm}$, as they are evenly distributed on the surface ( $\mathrm{z}$ on axis $\mathrm{y}$ ). With increasing the organic values and due to influence of buffer solution the particles size became from 200 to $1000 \mathrm{~nm}$.
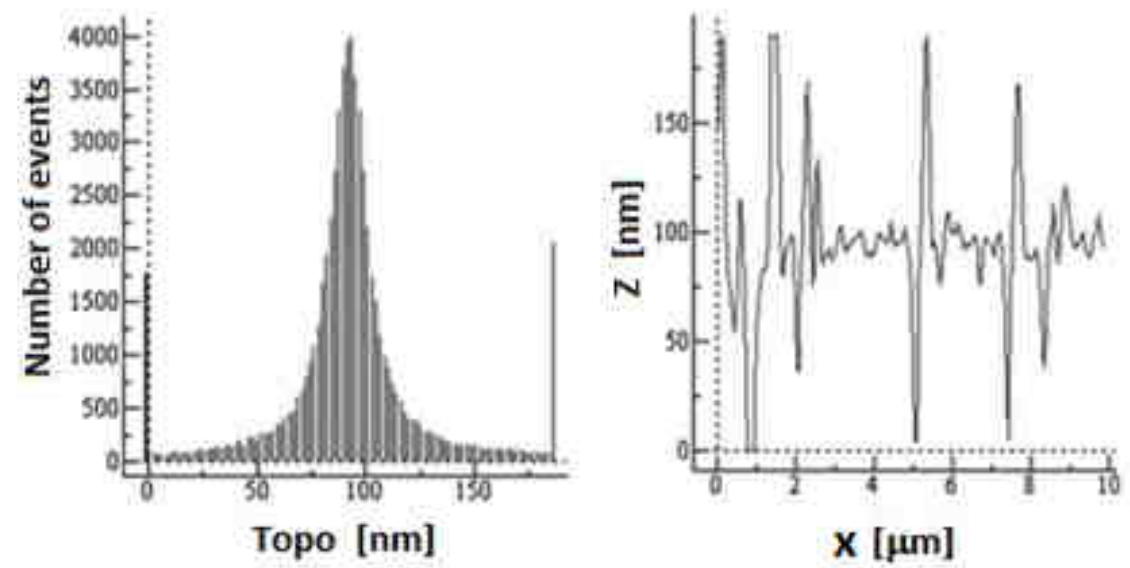

b)
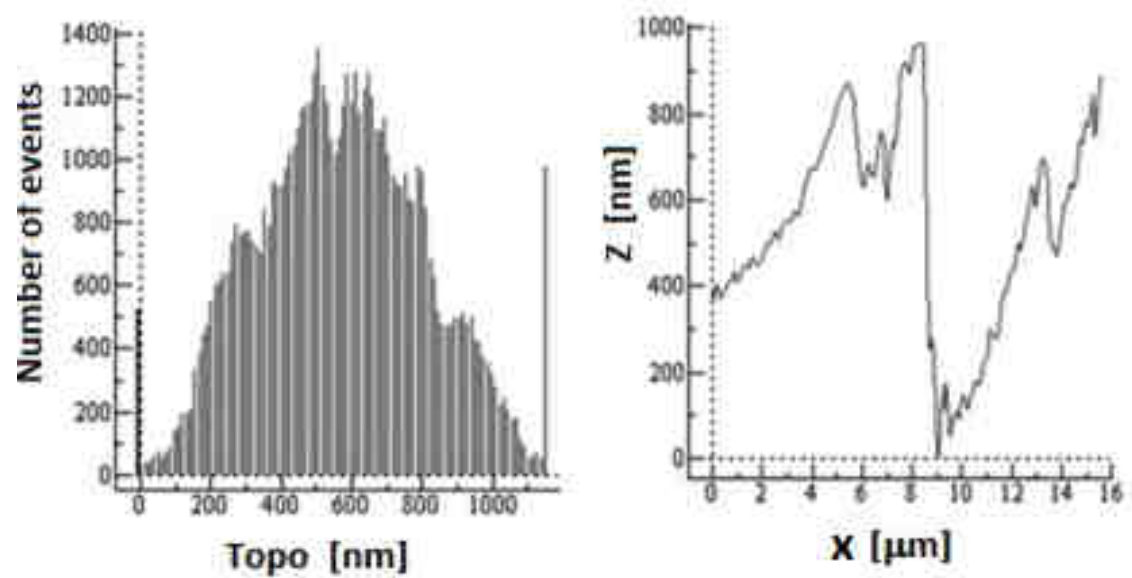

Fig. 5. Roughness analysis of synthesized hybrid materials: a) SiCSPCa1, b) SiCSPCa2 


\section{n-hexadecane biodegradation by free and entrapped cells}

Degradation of n-hexadecane using freely-suspended cells and immobilized cells of Pseudomonas aeruginosa strain $\mathrm{BN} 10$ at equal initial concentrations of the xenobiotic $\left(10 \mathrm{~g} / \mathrm{dm}^{3}\right.$ at the beginning of each cycle) and under similar conditions was monitored at the end of each reaction cycle by using gas chromatography.

Free cells of the investigated strain showed that they were capable to degrade n-hexadecane for 5 active cycles in a semicontinuous mode of operation. Each cycle began with the addition of $10 \mathrm{~g} / \mathrm{dm}^{3}$ of the xenobiotic. During this period almost $50 \mathrm{~g} / \mathrm{dm}^{3}$ n-hexadecane were degraded by the free cells of Pseudomonas aeruginosa strain BN10. The first three cycles ended for $48 \mathrm{~h}$ until total depletion of the xenobiotic added (Fig. 6a). The process was gradually retarded during the fourth cycle (duration of $72 \mathrm{~h}$ ) and fifth cycle $(96 \mathrm{~h})$. This fact was due to decrease in the vitality and catabolic capability of free cells. The end of each cycle was marked when almost the whole hexadecane quantity was depleted. The degraded quantity was $30 \mathrm{~g} / \mathrm{dm}^{3}$ for the first three cycles, $9 \mathrm{~g} / \mathrm{dm}^{3}$ for the fourth cycle and $5 \mathrm{~g} / \mathrm{dm}^{3}$ for the fifth cycle.

Immobilization technique was applied realizing the production of active preparations by the sol-gel method. Preliminary experiments were carried out for entrapment of the bacterial cells in both synthesized matrices which revealed the advantage of the carrier with higher percent of organic constituents [19]. Stepping on these results SiCSPCa2 was involved in our study. SiCSPCa2 is used for the first time for immobilization of the investigated strain. Two and three-fold inceased cell densities $\left(6.0 \cdot 10^{10} \mathrm{~g}^{-1}\right.$ carrier material and $9.0 \cdot 10^{10} \mathrm{~g}^{-1}$ carrier material) were prepared and used and the effect was followed. Concentration of $6.0 \cdot 10^{10} \mathrm{~g}^{-1}$ carrier material appeared to be the most appropriate for our purpose. Probably the increased concentration led to hindered mass transfer and the lowest one was insufficient.

Intensification of the biodegradation processes was achieved by employing cells entrapment. Fifteen consecutive active cycles of n-hexadecane biodegradation were successfully performed by the immobilized cells in sol-gel hybrids. The overall amount of degraded xenobiotic was almost $150 \mathrm{~g} / \mathrm{dm}^{3}$ (Fig. 6b).

These experiments were also performed by the addition of increasing concentrations of $\mathrm{n}$-hexadecane at the beginning of each cycle from 5 to $30 \mathrm{~g} / \mathrm{dm}^{3}$. The experiments demonstrated that the immobilized Pseudomonas aeruginosa BN10 cells have high catabolic ability up to a concentration of $30 \mathrm{~g} / \mathrm{dm}^{3}$ (Fig. 6c). Certain increase in the biodegradation rate was established for the first cycles and a slow decrease in the rate was registered when a slight inhibition of the process was observed at the highest concentration.

Based on the results obtained, it can be concluded that immobilized cells can resist higher concentrations of $n$-hexadecane and exhibit higher degradation rate compared to free cells. Liang et al. [20] also reported that immobilization in activated carbon biocarrier increased the biodegradation of crude oil, bacterial population and total microbial activity. Immobilized systems created were found to be the most successful in terms of percentage removal of the xenobiotic after 15 active cycles of operation. 

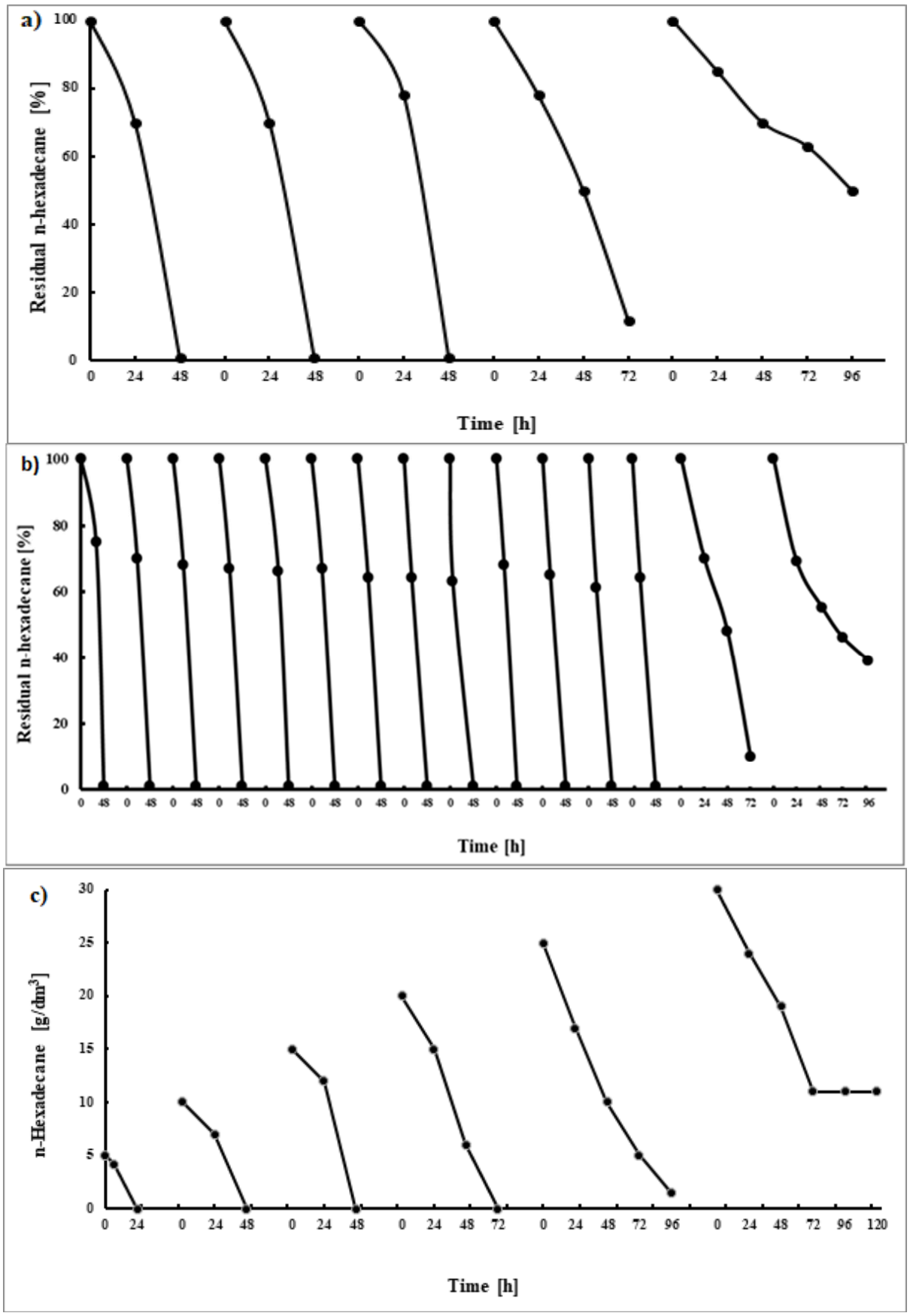

Fig. 6. Dynamics of n-hexadecane biodegradation by free (a), entrapped (b) cells of Pseudomonas aeruginosa BN10 and (c) - at gradual increase of xenobiotic concentrations. Average values between tree independent experiments are presented 
In addition, both free and immobilized cells degraded $100 \%$ of the added hexadecane within $48 \mathrm{~h}$ but the effectiveness of the immobilized cells for xenobiotic biodegradation was three times higher. The synthesized by the sol-gel method hybrid structures ensure good stability and performance of the cells entrapped there in, allowing the substrate to penetrate and to be biodegraded. Omar and Rehm [21] reported that Candida parapsilosis and Penicillium frequetans when immobilized on granular clay in columns, effectively degraded $\mathrm{C} 12$ to $\mathrm{C} 18$ alkanes with residuals of 13.4 to $32.3 \%$. According to Emtiazi et al. [22], biodegradation of petroleum oil by a Pseudomonas $s p$. isolated from a petroleum-contaminated soil after immobilization on perlite, were more stable for oil degradation. Gentili et al. [23] used chitin and chitosan flakes for immobilization of Rhodococcus corynebacterioides QBTo. These supports are natural, nontoxic, nonpolluting and biodegradable that are obtained from shrimps and crabs. Immobilization of $R$. corynebacterioides QBTo increased significantly the crude oil biodegradation [23].

Pseudomonads are the best known bacteria capable of utilizing hydrocarbons as carbon and energy sources and producing biosurfactants [24, 25]. In a previous study, Pseudomonas aeruginosa BN10 was proved to produce rhamnolipid type of biosurfactants [26]. Biosurfactants increase the oil surface area favouring the availability of oil for bacteria to utilize it [27]. The immobilized cells not only showed a higher efficiency of hexadecane degradation than free cells but could also degrade higher concentrations of this xenobiotic. This effect was also discussed by Das and Chandran [28]. Similar results were reported for petroleum hydrocarbon degradation with bacterial spores entrapped in chitosan beads [15]. In our case we suggest that the rhamnolipids synthesized by the strain (data not shown) also enhance n-hexadecane biodegradation. Rahman et al. [25] showed that there was no decline in the biodegradation activity of the microbial consortium on the repeated use, but the results for free and immobilized in alginate beads cells were comparable. In our case the difference in the ability of entrapped cells and free cells at repeated use was much greater. However, it was concluded that immobilization of cells in sol-gel hybrid structures is a promising application in the bioremediation of hydrocarbon contaminated sites.

Bioremediation is an eco-friendly method for removing of oil spills since it allows complete mineralization of pollutants [29], so together with application of the immobilization technique could be an effective biotechnological scheme for pollutants detoxification.

\section{Conclusions}

Silica hybrid materials with participation of chitosan and polyethylene glycol were synthesized via sol-gel technique. The obtained structures were amorphous, with evenly distributed organic particles throughout the inorganic network. The variation in inorganic/organic ratio showed that increasing of organic values lead to formation of rough, nonhomogeneous structures and the carrier with higher percent of organic constituents was chosen.

The synthesized by the sol-gel method hybrid matrices appeared to be suitable carriers for realizing an effective biodegradation process of n-hexadecane by Pseudomonas aeruginosa $\mathrm{BN10}$. This approach overcomes some problems with stability, reuse and long term cell viability encountered with free cells. Therefore, the immobilization method has been proven to be an effective system for the bioremediation of n-hexadecane used as a model compound of the aliphatic fraction of petroleum oil. 


\section{References}

[1] Singh S, Cameotra W, Singh P. Microb Cell Fact. 2009;8:16. DOI: 10.1186/1475-2859-8-16.

[2] Chénier MR, Beaumier D, Roy R, Driscoll BT, Lawrence JR, Greer CW. Appl Environ Microbiol. 2003;69:5170-5177. DOI: 10.1128/AEM.69.9.5170-5177.2003.

[3] Dabóczi M, Albert E, Agócs E, Kabai-Faix M, Hórvölgyi Z. Carbohydr Polym. 2016;136:137-145. DOI: 10.1016/j.carbpol.2015.09.025.

[4] Medina-Bellver JI, Marín P, Delgado A, Rodríguez-Sánchez A, Reyes E, Ramos JL, et al. Environ Microbiol. 2005;7:773-779. DOI: 10.1111/j.1462-2920.2005.00742.x.

[5] April TM, Foght JM, Currah RS. Can J Microbiol. 2000;46:38-49. DOI: 10.1139/cjm-46-1-38.

[6] Uche EC, Dadrasnia A. 2017 HC-0B-06: Biodegradation of Hydrocarbons. In: Heimann K, Karthikeyan O, Muthu S, editors. Biodegradation and Bioconversion of Hydrocarbons. Environmental Footprints and Eco-design of Products and Processes. Singapore: Springer; 2017. DOI: 10.1007/978-981-10-0201-4.

[7] Vanharova L, Julinova M, Slavik R. Ecol Chem Eng S. 2017;24(2):299-309. DOI: 10.1515/eces-2017-0021.

[8] Cassidy MB, Lee H, Trevors JT. J Ind Microbiol. 1996;16:79-101. DOI: 10.1007/BF01570068.

[9] Padil VVT, Wacławek S, Černík M. Ecol Chem Eng S. 2016;23(4):533-557. DOI: 10.1515/eces-2016-0038.

[10] Pandey S, Mishra SB. J Sol-Gel Sci Technol. 2011;59:73-94. DOI: 10.1007/s10971-011-2465-0.

[11] Elnashar MMM. J Biomat Nanobiotechnol. 2010;1:61-77. DOI: 10.4236/jbnb.2010.11008.

[12] Darder M, Aranda P, Ruiz-Hitzky E. Adv Mater. 2007;19:1309-1319. DOI: 10.1002/adma.200602328.

[13] Pandey RP, Shahi VK. J Membrane Sci. 2013;444:116-126. DOI: 10.1016/j.memsci.2013.04.065.

[14] Bayat Z, Hassanshahian M, Cappello S. Open Microbiol. 2015;9:48-54. DOI: 10.2174/1874285801509010048.

[15] Barreto RVG, Hissa DC, Paes FA, Grangeiro TB, Nascimento RF, Rebelo LM, et al. Bioresour Technol. 2010;101:2121-2125. DOI: 10.1016/j.biortech.2009.11.004.

[16] Ulrici W. Contaminated Soil Areas, Different Countries and Contaminants, Monitoring of Contaminants. Chapter 1. In: Rehm HJ, Reed G, editors. Biotechnology: Environmental Processes II. 2008;11:5-42. DOI: 10.1002/9783527620951.ch1.

[17] Díaz MP, Boyd KG, Grigson SJW, Burgess JG. Biotechnol Bioeng. 2002;79:145-153. DOI: 10.1002/bit.10318.

[18] Shirosaki Y, Okamoto K, Hayakawa S, Osaka A, Asano T. Biomed Res Int. 2015;2015: 392940. DOI: $10.1155 / 2015 / 392940$.

[19] Tsekova KV, Chernev GE, Hristov AE, Kabaivanova LV. Z Naturforsch C. 2013;68(1-2):53-59. https://www.ncbi.nlm.nih.gov/pubmed/23659173.

[20] Liang Y, Zhang X, Dai D, Li G. Int Biodeterior Biodegrad. 2009;63:80-87. https://doi.org/10.1016/j.ibiod.2008.07.005.

[21] Omar SH, Rehm HJ. Appl Microbiol Biotechnol. 1988;28(1):103-108. DOI: 10.1007/BF00250507.

[22] Emtiazi G, Shakarami H, Nahvi I, Mirdamadian A. African J Biotechnol. 2005;4(2):172-176. DOI: 10.5897/AJB2005.000-3034.

[23] Gentili AR, Cubitto MA, Ferrero M, Rodrigues MS. Int Biodeterior Biodegrad. 2006;57:222-228. DOI: 10.1016/j.ibiod.2006.02.009.

[24] Nikolopoulou M, Kalogerakis N. J Chemical Technol Biotechnol. 2009;84:802-807. DOI: $10.1002 /$ jctb. 2182 .

[25] Rahman RNZA, Ghazali FM, Salleh AB, Basri M. J Microbiol. 2006;44:354-359. https://www.ncbi.nlm.nih.gov/pubmed/16820766.

[26] Christova N, Tuleva B, Cohen R, Ivanova G, Stoev G, Stoilova-Disheva M, et al. Z Naturforsch C. 2011;66(7-8):394-405. http://www.znaturforsch.com/s66c/s66c0394.pdf.

[27] Kumar V, Singh S, Manhasi A, Negi P, Singla S, Kaur P, et al. Oriental J Chem. 2014;30(4):1771-1776. DOI: $10.13005 / \mathrm{ojc} / 300436$.

[28] Das N, Chandran P. Biotechnol Res Int. 2011; Article ID 941810. DOI: 10.4061/2011/941810.

[29] Ward OP. J Ind Microbiol Biotechnol. 2004;31(1):1-4. DOI: 10.1007/s10295-004-0109-x. 